\title{
PERSEPSI MASYARAKAT KOTA BENGKULU TERHADAP PAHAM ISLAM MODERAT
}

\author{
Wahyu Abdul Jafar \\ Fakultas Syariah IAIN Bengkulu \\ J. Raden Fatah Pagar Dewa Bengkulu \\ Email: wahyujabar@gmail.com
}

\begin{abstract}
This research was conducted to describe the perception of resident of Bengkulu about moderate Islamic understanding. In collecting the research data, researchers used purposive sampling technique. While the data collection techniques used are interviews and documentation. From the research in the field, important conclusions were obtained namely, resident of bengkulu has some perception about moderate Islamic understanding, among others: first, Moderate Islamic understanding is the teachings of Islam that is tasamuh (tolerant), tawazun (balanced), i'tidal (straight) and tawasuth (mediocre). Secondly, Moderate Islamism is the Islamic teaching that is Rahmatan Lil Alamin. Thirdly, moderate Islamic understanding is a humanist teaching, humanistic, gentle, polite, not anarchic and peace-loving. Fourthly, Moderate Islamism is an Islamic teaching that opens itself with progress and in harmony with the concept of Indonesian statehood. Fifth, Moderate Islamism is the Islamic teachings of Islam that prioritize the value of the unity and integrity of the nation and the state. Sixth, Moderate Islamism is the teachings of Islam which emphasizes the amar marufnya side of the nahi mungkarnya side. Seventh, Moderate Islamism is a strictly Islamic teaching for the afterlife and flexible for world affairs. Eighth, Moderate Islamism is a liberal and perverted teaching of Islam. Ninth, Moderate Islamism is an Islamic teaching that is heretical and weakens the Islamic ummah. Tenth, Islamic understanding Moderet is the Islamic teaching that is a mirage and divide the Muslims.
\end{abstract}

Keywords: understanding of moderate Islam, perception, Bengkulu

\begin{abstract}
Abstrak: Penelitian ini dilakukan untuk mendeskripsikan persepsi masyarakat kota Bengkulu terhadap paham Islam Moderat. Dalam mengumpulkan data penelitian, peneliti menggunakan teknik purposif sampling. Sedangkan teknik pengumpulan data yang digunakan adalah wawancara dan dokumentasi. Dari penelitian di lapangan diperoleh kesimpulan penting yakni masyarakat kota Bengkulu memiliki beberapa persepsi tentang paham Islam moderat, antara lain: pertama, paham Islam Moderat adalah ajaran Islam yang bersifat tasamuh (toleran), tawazun (berimbang), i'tidal (lurus) dan tawasuth (sedang-sedang). Kedua, paham Islam Moderat adalah ajaran islam yang bersifat Rahmatan lil Alamin. Ketiga, paham Islam Moderat adalah ajaran Islam yang bersifat humanis, lembut, santun, tidak anarkis dan cinta damai. Keempat, paham Islam Moderat adalah ajaran islam yang membuka diri dengan kemajuan dan selaras dengan konsep kenegaraan Indonesia. Kelima, paham Islam Moderat adalah ajaran Islam yang mengedepankan nilai nilai persatuan dan keutuhan berbangsa dan bernegara. Keenam, paham Islam Moderat adalah ajaran Islam yang lebih menekankan sisi amar ma’rufnya dari pada sisi nahi mungkarnya. Ketujuh, paham Islam Moderat adalah ajaran Islam yang bersifat tegas untuk urusan akhirat dan lentur untuk urusan dunia. Kedelapan, paham Islam Moderat adalah ajaran Islam yang bersifat liberal dan sesat. Kesembilan, paham Islam Moderat adalah ajaran Islam yang bersifat bid'ah dan melemahkan umat Islam. Kesepuluh, paham Islam Moderat adalah ajaran Islam yang bersifat fatamorgana dan memecah belah umat Islam.
\end{abstract}

Kata kunci: paham Islam Moderat, persepsi, Bengkulu

\section{Pendahuluan}

Paham Islam Moderat merupakan suatu paham yang mengedepankan rasa saling hormatmenghormati, tidak saling salah-menyalahkan, tidak saling merasa paling benar sendiri, dan bersedia berdialog ketika terjadi sebuah perbedaan. Paham Islam Moderat ini sangat urgen untuk disebarkan di masyarakat luas guna menangkal berkembangnya paham radikal $^{1}$

\footnotetext{
${ }^{1}$ Radikalisme merupakan fenomena modern dan kontemporer,
} 
dalam agama Islam. Paham radikal apabila dibiarkan tumbuh subur di tengah masyarakat tentu akan menimbulkan sikap intoleransi ketika menyikapi perbedaan pandangan dalam agama yang bisa mengancam keutuhan Negara Kesatuan Republik Indonesia (NKRI).

Masih belum hilang dalam ingatan, fenomena kasus intoleransi dalam beragama yang terjadi sepanjang dua tahun terakhir, yakni kasus pembakaran tempat ibadah umat muslim dan 70 rumah umat muslim di Tolikara Papua yang terjadi pada hari Jumat tanggal 17 juli $2015^{2}$ serta kasus pembakaran satu Vihara dan empat Kelenteng di Tanjung Balai Sumatera Utara pada tanggal 29 Juli $2016^{3}$.

Contoh kasus di atas tidak menutup kemungkinan bisa menular juga ke kota Bengkulu, apabila tidak dilakukan upaya pencegahan melalui penguatan paham Islam Moderat. Apalagi masyarakat kota Bengkulu terdiri dari masyarakat yang heterogen. Hal ini dapat dilihat pada tabel dibawah ini:

\begin{tabular}{lccccc}
\hline & \multicolumn{5}{c}{ Jenis Agama } \\
\cline { 2 - 6 } Kategori & Islam & Protestan & Katolik & Hindu & Budha \\
\hline $\begin{array}{l}\text { Pemeluk } \\
\text { Agama }\end{array}$ & 368.229 & 58.706 & 129 & 540 & 1.059 \\
\hline Kategori & Masjid & $\begin{array}{c}\text { Gereja } \\
\text { Protestan }\end{array}$ & $\begin{array}{c}\text { Gereja } \\
\text { Katolik }\end{array}$ & Pura & Vihara \\
\hline $\begin{array}{l}\text { Rumah } \\
\text { Ibadah }\end{array}$ & 389 & 2 & 12 & 2 & 2 \\
\hline
\end{tabular}

Sumber : Data Badan Pusat Statistik Kota Bengkulu ${ }^{4}$

dan merupakan reaksi terhadap munculnya nasionalisme sekular. Ideologi radikalisme menggambarkan respons langsung terhadap munculnya negara-bangsa yang merdeka. Militansi dan radikalisme Islam menggambarkan sintesis kreatif revivalisme dan reformisme. Gerakan radikal berpandangan kolot dan sering menggunakan kekerasan dalam mengajarkan keyakinan mereka. Syamsul Bakri, "Islam dan Wacana Radikalisme Kontemporer". DINIKA. Vol. 3 No. 1, Januari 2004, h. 3.

${ }^{2}$ www.tempo.co, didownloud pada tanggal 30 Januari 2017

3 www.m.tribunews.com, didownloud pada tanggal 30 Januari 2017

${ }^{4}$ BPS Provinsi Bengkulu, Provinsi Bengkulu Dalam Angka 2016, (Bengkulu: Perum Percetakan Negara RI Cabang Bengkulu, 2016), h. 182-184
Keberagaman beragama yang ada di kota Bengkulu perlu dikelola dengan arif dan bijaksana untuk menghindari terjadinya kasus intoleransi beragama. Upaya pencegahan terjadinya kasus intoleransi beragama seperti yang dicontohkan di atas, bisa dilakukan sejak dini yakni dengan cara mengetahui persepsi masyarakat kota Bengkulu terhadap urgensi paham Islam Moderat. Mengetahui persepsi masyarakat ini sangat penting sekali untuk menjadi barometer awal dalam mencegah terjadinya kasus intoleransi. Ada beberapa contoh sikap yang bisa memicu terjadinya sikap intolerani, dan konflik di tengahtengah masyarakat kota Bengkulu apabila dibiarkan begitu saja tanpa ada penanganan yang khusus, hal ini sebagaimana kutipan wawancara pra survey, antara lain:

"Katanya umat Islam ikut Nabi Muhammad tapi buktinya banyak amalan ibadah mereka yang buat-buat sendiri. Yasinan, tahlilan dan selametan itu dari budaya hindu tapi malah mereka lakukan, ahli bid'ah semua mereka kalau masuk neraka baru tau rasa nanti" ${ }^{\prime \prime}$

Wawancara selanjutnya, "lebih baik salat jama'ah di sini saja mas jangan di tempat lain, tidak sah nanti karena imamnya melafalkan niat sebelum takbir. Melafalkan niat kalau menurut ustad kami termasuk bid'ah karena tidak ada hadisnya. Logikanya kalau melafalkan niat ajaran dari Nabi tentu ada hadisnya kan."6

Wawancara selanjutnya, "Jangan campurkan agama dan budaya. Agama ya agama budaya ya budaya. Masyarakat kita ini banyak yang salah kaprah mengikuti budaya malah meningalkan ajaran agama islam yang murni". 7

Wawancara selanjutnya, "saya males salat di masjid sana mas, nggak sealiran dengan saya. Subuhnya pakai qunut". ${ }^{8}$

Wawancara selanjutnya, "Di masjid sini

${ }^{5}$ Wawancara dengan Bapak Ahmad pada tanggal 29 Maret 2017.

${ }^{6}$ Wawancara dengan Bapak Darto pada tangal 24 Maret 2017.

${ }^{7}$ Wawancara dengan Bapak Rijal pada tangal 27 Maret 2017

${ }^{8}$ Wawancara dengan Bapak Muzakki pada tangal 24 Maret 2017. 
pernah tengkar mas antar jama'ah gara-gara habis salat harus wiridan setelah sholat berjama'ah atau wiridan sendiri-sendiri" ${ }^{9}$

Dari data prasurvey diatas dapat diketahui bahwa bibit-bibit munculnya sikap intoleransi sudah ada dan apabila dibiarkan begitu saja akan berdampak pada berkembangnya paham intoleran dalam beragama yang tidak menutup kemungkinan munculkan sikap radikal.

Upaya deteksi dini ini apabila dimaksimalkan bisa menjadi benteng yang kokoh dalam membentengi masyarakat kota Bengkulu dari pahampaham yang radikal. Berdasarkan fakta inilah, peneliti merasa tertarik dan ingin melakukan kajian secara mendalam tentang persepsi masyarakat kota Bengkulu terhadap paham Islam Moderat.

Berdasarkan latar belakang masalah yang telah peneliti paparkan di atas, maka peneliti membuat rumusan masalah, bagaimana persepsi masyarakat kota Bengkulu terhadap paham Islam Moderat?

Adapun tujuan penelitian ini untuk mengetahui secara detail persepsi masyarakat kota Bengkulu terhadap paham Islam Moderat.

\section{Penelitian Terdahulu}

Penelitian terkait Persepsi Masyarakat Kota Bengkulu Terhadap Urgensi Paham Islam Moderat belum pernah dilakukan sebelumnya, namun ada beberapa penelitian yang memiliki keterkaitan dengan penelitian ini, antara lain:

Pertama, Miftahuddin ${ }^{10}$, melakukan penelitian yang berjudul "Islam Moderat Konteks Indonesia Dalam Perspektif Historis”. Penelitian yang dilakukan oleh Miftahuddin ini mencoba melihat kembali bagaimana cara memahami Islam dan ber-Islam yang seharusnya diterapkan dalam konteks Indonesia sehingga tidak terjebak ke dalam ekstrimitas yang berlebihan.

\footnotetext{
9 Wawancara dengan Bapak Yanto pada tangal 29 Maret 2017.

10 Miftahuddin, Dosen Prodi Ilmu Sejarah, Jurusan Pendidikan Sejarah, FISE UNY, "Islam Moderat Konteks Indonesia Dalam Perspektif Historis".
}

Dari penelitianya dihasilkan kesimpulan bahwa Paham "Islam moderat", pada dasarnya hanyalah sebatas tawaran yang semata-mata ingin membantu masyarakat pada umumnya dalam memahami Islam. Bersikap moderat dalam berIslam bukanlah suatu hal yang menyimpang dalam ajaran Islam, karena hal ini dapat ditemukan rujukannya, baik dalam al-Qur'an, alHadits, maupun perilaku manusia dalam sejarah. Mengembangkan pemahaman "Islam moderat" untuk konteks Indonesia dapatlah dianggap begitu penting. Bukankah diketahui bahwa di wilayah ini terdapat banyak paham dalam Islam, beragam agama, dan multi-etnis. Paham "Islam moderat mengajak, bagaimana Islam dipahami secara kontekstual, memahami bahwa perbedaan dan keragaman adalah sunnatullah, tidak dapat ditolak keberadaannya. Jika hal ini diamalkan, dapat diyakini Islam akan menjadi agama rahmatan lil alamin.

Penelitian yang dilakukan oleh Miftahuddin berbeda dengan yang peneliti kaji dalam beberapa hal, antara lain: pertama jenis penelitian. Penelitian yang dilakukan oleh Miftahuddin jenisnya library research sedangkan jenis penelitian yang dilakukan oleh peneliti jenisnya field research. Perbedaan yang kedua dari fokus penelitiannya, penelitian yang dilakukan oleh Miftahuddin fokus penelitianya adalah Historis Islam Moderat yang ada di Indonesia sedangkan penelitian yang penulis lakukan fokusnya adalah persepsi masyarakat kota Bengkulu terhadap urgensi Paham Islam Moderat.

Kedua, Imam Mustofa, melakukan penelitian yang berjudul "persepsi dan resistensi aktifis muslim kampus terhadap paham dan gerakan islam radikal (studi di perguruan tinggi di propinsi lampung)". Penelitian ini berusaha menelisik dan mengungkap ketahanan mahasiswa di propinsi Lampung terhadap paham dan gerakan Islam radikal. Penelitian ini adalah penelitian lapangan (field research) yang bersifat kualitatif. Populasi penelitian ini adalah mahasiswa di empat perguruan Tinggi di propinsi Lampung, yaitu mahasiswa Universitas Lampung (Unila) mahasiswa Institut Agama Islam Negeri (IAIN) Raden Intan Lampung, mahasiswa Universitas Muhammadiyah Metro, dan maha- 
siswa Sekolah Tinggi Agama Islam Ma'arif (STAIM) Metro. Teknik sampling yang digunakan adalah purposive sampling. Teknik pengumpulan data dengan cara wawancara dan dokumentasi. Data yang terkumpul dianalisis dengan metode deskriptif-analitis. Sementara pendekatan yang digunakan dalam penelitian ini adalah pendekatan fenomenologi dan interaksi simbolik. Hasil penelitian ini menunjukkan bahwa mayoritas aktifis memandang gerakan Islam radikal sebagai ancaman terhadap Negara Kesatuan Republik Indonesia (NKRI). Namun demikian, keberadaan $23 \%$ responden yang berpandangan sebaliknya, yaitu bahwa Islam radikal tidak membahayakan eksistensi NKRI, tidak dapat dikatakan sebagai angka yang tidak signifikan. Pandangan mayoritas atau minoritas tidak selalu dapat diasosiasikan dengan latar belakang organisasi para aktivis Muslim kampus. Mereka mempunyai ketahanan yang cukup kuat terhadap pengaruh paham dan gerakan Islam radikal. Mereka juga mempunyai resistensi yang cukup kuat terhadap berbagai media dan sarana yang biasa digunakan kalangan Islam radikal untuk melakukan propaganda dan mencari kader. Kuatnya ketahanan mahasiswa tersebut dipengaruhi oleh faktor pendidikan, pemahaman agama serta faktor lingkungan dan pergaulan. Secara hirarkis mayoritas responden akan melakukan resistensi melalui cara-cara yang santun dan persuasif; sekelompok responden tidak menunjukkan resistensi secara eksplisit; dan segelintir responden akan melakukan resistensi secara tegas. Ketegasan yang dimaksud tidak merujuk pada respon frontal, melainkan pada upaya untuk menopang sikap resistensi dengan beradu argumen.

Penelitian yang dilakukan oleh Imam Mustofa ini berbeda dengan yang peneliti kaji. Perbedaan tersebuat terdapat dalam aspek, antara lain: pertama dari aspek fokus penelitian. Penelitian yang dilakukan oleh Imam Mustofa adalah resistensi aktifis muslim kampus terhadap paham dan gerakan islam radikal sedangkan penelitian yang penulis lakukan fokusnya adalah persepsi masyarakat kota Bengkulu terhadap urgensi Paham Islam Moderat. Yang kedua dari aspek tempat penelitian, Penelitian yang dilakukan oleh Imam Mustofa bertempat di provinsi lampung sedangkan penelitan yang peneliti buat bertempat di kota Bengkulu.

\section{Metode Penelitian}

Dalam masalah metode penelitian, setidaknya ada beberapa poin yang perlu diperhatikan guna menunjang kesuksesan suatu penelitian yang dilakukan. Beberapa poin tersebut antara lain: pertama, jenis penelitian yang peneliti lakukan guna mengungkapkan fakta terkait masalah Persepsi Masyarakat Kota Bengkulu Terhadap Urgensi Paham Islam Moderat adalah penelitian field research (penelitian lapangan). ${ }^{11}$ Dalam penilitian ini, peneliti akan melakukan pengalian data secara mendalam dan melakukan analisis secara intensif mengenai Persepsi Masyarakat Kota Bengkulu Terhadap Urgensi Paham Islam Moderat serta sebelumnya akan digali juga fakta-fakta tentang Persepsi Masyarakat Kota Bengkulu Terhadap Paham Islam Moderat itu sendiri, karena tidak menutup kemungkin masyarakat Kota Bengkulu berbeda persepsi dalam memahami Islam Moderat.

Kedua, lokasi dan waktu penelitian. Sesuai dengan judul yang diangkat dalam penelitian ini, maka penelitian ini berlokasi di Kota Bengkulu. Alasan pemilihan lokasi ini karena Kota Bengkulu adalah pusat aktivitas dari penduduk bengkulu sehinga diharapkan data yang akan terkumpul berasal dari ragam varian yang lebih banyak. Sedangkan waktu pelaksanaan penelitian ini kurang lebih 6 (enam bulan) sebagaimana terlampir dalam jadwal penelitian.

Ketiga, sumber data penelitian. Yang dimaksud sumber data dalam penelitian ini adalah subyek darimana data diperoleh. Dalam penelitian ini, ada beberapa sumber data yang

${ }^{11}$ Case study research and field study research (Penelitian kasus dan penelitian lapangan) adalah penelitian yang bermaksud mempelajari secara intensif tentang latar belakang keadaan sekarang dan interaksi suatu sosial, individu, kelompok, lembaga dan masyarakat. Husaini Usman dan Purnomo Setiady Akbar, Metodologi Penelitian Sosial, (Jakarta: PT Bumi Aksara, 2003), h. 5. 
digunakan oleh peneliti sebagai bahan rujukan, antara lain: Sumber Data Primer, sumber data primer peneliti dalam penelitian ini hanya katakata dan tindakan Masyarakat Kota Bengkulu Terhadap Urgensi Paham Islam Moderat. Sumber data primer tersebut oleh peneliti akan dicatat melalui catatan tertulis. Sumber Data Sekunder, Sumber data sekunder yaitu sumber yang secara tidak langsung berkaitan dengan objek penelitian ini tetapi dirasa sangat mendukung dalam penelitian, baik berupa buku-buku, artikel, koran, dan lain sebagainya yang berkaitan dengan Persepsi Masyarakat Kota Bengkulu Terhadap Urgensi Paham Islam Moderat.

Keempat, teknik pengumpulan data. Dalam penelitian ini, peneliti menggunakan dua teknik dalam mengumpulkan data-data penelitian, yaitu: Wawancara (Interview) dan dokumentasi. Peneliti melakukan wawancara menggunakan teknik wawancara tak tersetuktur. ${ }^{12}$ Teknik ini peneliti pilih karena lebih bersifat luwes dan dirancang agar sesuai dengan subjek dan suasana pada wawancara berlangsung. Teknik dokumentasi peneliti lakukan dengan cara mengumpulkan dokumen-dokumen dan literatur yang memiliki keterkaitan dengan persoalan persepsi masyarakat kota Bengkulu terhadap urgensi paham Islam Moderat.

Kelima, teknik analisis data. Teknik analisa data yang digunakan dalam penelitian ini adalah analisa kualitatif ${ }^{13}$ dengan pola berfikir induktif. Analisa induktif yang dimaksud adalah analisa yang berangkat dari data yang bersifat khusus kemudian ditarik kesimpulannya yang bersifat umum. Dalam Penelitian kualitatif ini, peneliti akan melalui tiga komponen pokok, yaitu,

\footnotetext{
${ }^{12}$ Teknik wawancara terbagi menjadi dua macam, wawancara berstruktur dan wawancara tak tersetuktur. Dalam wawancara berstruktur pertanyaan dan alternatif jawaban yang diberikan kepada interviewee telah ditetapkan terlebih dahulu, sedangkan pada pada wawancara tak terstruktur pertanyaan-pertanyaan dapat diajukan secara bebas kepada subjek. Ibid., h. 180.

${ }^{13}$ Analisa kualitatif artinya menguraikan data secara bermutu dalam bentuk kalimat yang teratur, runtun, logis, tidak tumpang tindih, dan efektifsehingga memudahkan pemahaman dan interpretasi data, Abdul Kadir Muahammad, Hukum dan Penelitian Hukum, (Jakarta: PT. Citra Aditya Bhakti, 2004), h. 172
}

data reduction, data display dan data conclusion drawing. ${ }^{14}$ Tiga komponen ini akan saling berkaitan baik sebelum, pada waktu dan setelah pelaksanaan pengumpulan data. Analisis ini pada umumnya disebut dengan model analisis mengalir atau flow model of analysis.

\section{Pembahasan}

\section{Teori Persepsi}

Persepsi merupakan suatu proses yang didahului oleh penginderaan yaitu merupakan proses yang berwujud diterimanya stimulus oleh individu melalui alat reseptornya. Untuk lebih memahami persepsi berikut adalah beberapa definisi peresepsi menurut pakar psikologi antara lain sebagai berikut:

Persepsi merupakan penafsiran yang terorganisir terhadap suatu stimulus serta mampu mempengaruhi sikap dan perilaku. Persepsi adalah proses penginterpretasian seseorang terhadap stimulus sensori. Proses sensori tersebut hanya melaporkan lingkungan stimulus. Persepsi menerjemahkan pesan sensori dalam bentuk yang dapat dipahami dan dirasakan.

Persepsi adalah penelitian bagaimana kita mengintegrasikan sensori ke dalan perspect obyek dan bagaimana kita selanjutnya menggunakan perspect itu untuk mengenali dunia (Perspect adalah hasil dari perspectual). ${ }^{15}$

Dengan demikian dari pengertianpengertian persepsi di atas dapat disimpulkan bahwa persepsi adalah proses pengorganisasian dan proses penafsiran/ penginterpretasian seseorang terhadap stimulasi yang dipengaruhi oleh berbagai pengetahuan, keinginan, dan pengalaman yang relevan terhadap stimulasi yang dipengaruhi perilaku manusia dalam menentukan tujuan hidupnya.

Agar individu dapat melakukan persepsi ada beberapa syarat yang harus dipenuhi, yaitu:

\footnotetext{
${ }^{14}$ Sugiyono, Model Penelitian kuantitatif kualitatif, (Bandung: Alfabeta, 2010), h. 247-253

${ }^{15}$ Atkinson dkk, Pengantar Psikologi Jilid II, (Batam: Intereksa, 1987), h. 277
} 
a) Adanya objek yang dipersepsikan, objek menimbulkan stimulus yang mengenai alat indera atau reseptor. Stimulasi dapat datang dari luar langsung mengenai alat indera (reseptor) dapat datang dari dalam yang langsung mengenai syaraf penerima (sensoris) yang bekerja sebagai reseptor.

b) Adanya alat indera atau reseptor yang cukup baik, yaitu alat untuk menerima stimulus. Di samping itu harus ada pula syaraf sensoris sebagai alat untuk meneruskan stimulus yang diterima reseptor ke pusat susunan syaraf sensoris yaitu otak sebagai pusat kesadaran. Dan sebagai alat untuk mengadakan respons diperlukan syaraf motoris.

c) Untuk menyadari atau untuk mengadakaan persepsi sesuatu diperlukan pula adanya perhatian yang merupakan langkah pertama sebagai suatu persiapan dalam mengadakan persepsi. Tanpa perhatian tidak akan terjadi persepsi. $^{16}$

Persepsi seseorang terhadap suatu objek dapat berbeda dengan orang lain. Perbedaan tersebut dipengaruhi oleh berbagai faktor. Cara kita mempersepsikan situasi sekarang tidak bisa terlepas dari adanya pengalaman sensoris terdahulu. Kalau pengalaman terdahulu itu sering muncul, maka reaksi kita selalu menjadi kebiasaan secara ilmiah benar mengingat responrespon perseptual yang ditunjukkannya.

Mungkin sembilan puluh persen dari pengalaman-pengalaman sensoris kita seharihari dipersepsikan dengan kebiasaan yang didasarkan pada pengalaman terdahulu yang diulang-ulang. ${ }^{17}$ Oleh sebab itu, apa yang kita persepsikan pada suatu waktu tertentu akan tergantung bukan saja pada stimulusnya sendiri, tetapi juga pada latar belakang beradanya stimulus itu.

Seperti pengalaman-pengalaman sensoris kita yang terdahulu, perasaan kita pada waktu itu,

\footnotetext{
${ }^{16}$ Su'adah, Fauzik Lendriyono, Pengantar Psikologi, (Malang: Bayumedia Publishing, 2003), h. 32

${ }^{17}$ Dimyati Mahmud, Psikologi Suatu Pengantar, (Jakarta: BPFE, 1990), h. 41
}

prasangka-prasangka, keinginan-keinginan, sikap dan tujuan. Kalau di satu pihak proses kognitif saling berkaitan satu sama lain. Kita akan mulai dengan persepsi dianggap sebagai pertemuan antara kognisi dan kenyataan-kenyataan dan juga dianggap sebagai sumber utama dari aktivitas kognitif. ${ }^{18}$ Berikut ini dikemukakan beberapa faktor yang mempengaruhi persepsi seseorang menurut para ahli mengemukakan bahwa ada tiga faktor penting yang mempengaruhi persepsi yaitu pegetahuan (knowledge), harapan (expectations) dan penilaian (evaluation).

Ada tiga faktor yang mempengaruhi persepsi terhadap orang lain yaitu (a) keadaan stimulus dari orang yang dipersepsi, (b) situasi sosial tempat mana stimulus berada, (c) keadaan atau karakteristik dari orang yang mempersepsi (perseptor).

\section{Konsep Islam Moderat}

Istilah Islam Moderat bukan sengaja dibuatbuat tanpa ada dasarnya sama sekali, melainkan istilah Islam Moderat sudah memiliki konsep dan landasan yang jelas. Bahkan, istilah islam moderat muncul dengan dasar atau landasan teologis dan ontologis (sesuatu yang bersifat konkret). Istilah Islam moderat ialah bagian dari ajaran Islam yang universal. Istilah Islam moderat memiliki padanan dengan istilah Arab ummatan wasathan atau al-din al-wasath. al ini sebagai mana firman Allah Swt:

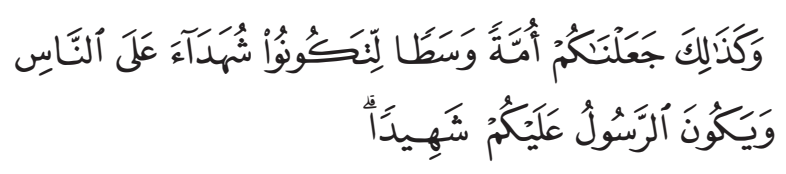

"Dan demikianlah Aku (Tuhan) jadikan kalian umat yang "wasath" (adil, tengah-tengah, terbaik) agar kalian menjadi saksi (syuhada') bagi semua manusia, dan agar Rasul (Muhammad saw) menjadi saksi (syahid) juga atas kalian." (Q.S. Al-Baqarah143:[2] ).

Istilah Umatan wasathan dalam ayat tersebut berarti "golongan atau agama tengah". Kata

\footnotetext{
${ }^{18}$ Davidoff Linda, Psikologi Suatu Pengantar, (Jakarta: Erlanga, 1988), h. 248
} 
"wasat" dalam ayat di atas, jika merujuk kepada tafsir klasik seperti al-Tabari atau al-Razi, mempunyai tiga kemungkinan pengertian, yakni: umat yang adil, tengah-tengah, atau terbaik. Ketiga pengertian itu, pada dasarnya, saling berkaitan.

Sebagai istilah untuk penggolongan corak pemikiran dan gerakan istilah "Islam moderat" diperlawankan dengan istilah lain, yaitu Islam radikal. Islam moderat, dalam pengertian yang lazim kita kenal sekarang, adalah corak pemahaman Islam yang menolak cara-cara kekerasan yang dilakukan oleh kalangan lain yang menganut model Islam radikal. ${ }^{19}$

Paham Islam moderat memiliki beberapa nilai-nilai luhur yang harus diperhatikan, antara lain: ${ }^{20}$

a. Tawassuth

Yang dimaksud dengan sikap tawasuth disini adalah sikap tengah-tengah, sedang-sedang, tidak ekstrim kiri ataupun ekstrim kanan. Ini disarikan dari firman Allah Swt:

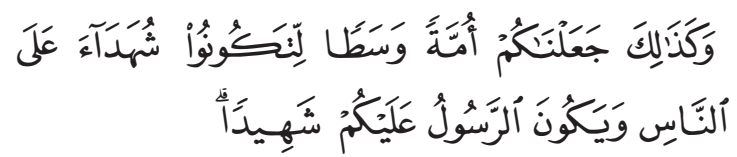

"Dan demikianlah kami jadikan kamu sekalian (umat Islam) umat pertengahan (adil dan pilihan) agar kamu menjadi saksi (ukuran penilaian) atas (sikap dan perbuatan) manusia umumnya dan supaya Rosulloh menjadi saksi (ukuran penilaian) atas (sikap dan perbuatan) kamu sekalian... (QS al-Baqarah: 143).

b. Tawazun

Yang dimaksud dengan tawazun disini adalah seimbang dalam segala hal, temasuk dalam penggunaan dalil 'aqli (dalil yang bersumber dari akal pikiran rasional) dan dalil naqli (bersumber dari Alquran dan hadis). Firman Allah Swt:

${ }^{19}$ Diakses dari mynewblogaddressislam.blogspot.co.id pada tanggal 28 Juli 2017

${ }^{20}$ Diakses dari http://www.nu.or.id/post/read/16551/karaktertawassuth-tawazun-i039tidal-dan-tasamuh-dalam-aswaja. Pada tanggal 1 Februari 2017

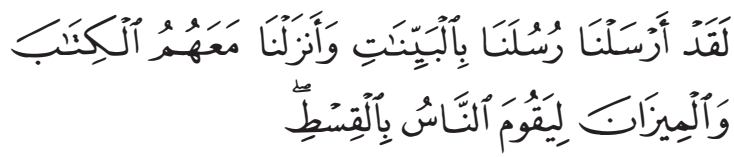

"Sunguh kami telah mengutus rasul-rasul kami dengan membawa bukti kebenaran yang nyata dan telah kami turunkan bersama mereka alkitab dan neraca (penimbang keadilan) supaya manusia dapat melaksanakan keadilan... (QS al-Hadid: 25) ${ }^{21}$

Ayat di atas menjelaskan kepada kita bahwa selain al-kitab ada lagi al-mizan yang dijadikan pijakan dalam menjalankan keadilan di dunia ini. Para ulama kemudian menafsiri al-Mizan dengan akal pikiran yang sehat. Namun, sesuai dengan ayat di atas yang menjadi barometer awal adalah al-kitab, baru kemudian al-mizan, bukan dibalik almizan dulu baru al-kitab.

c. I'tidal

Yang dimaksud dengan i'tidal disini adalah tegak lurus. Konsisten dalam melaksanakan aturan tidak melihat unsur benci atau suka. Firman Allah Swt:

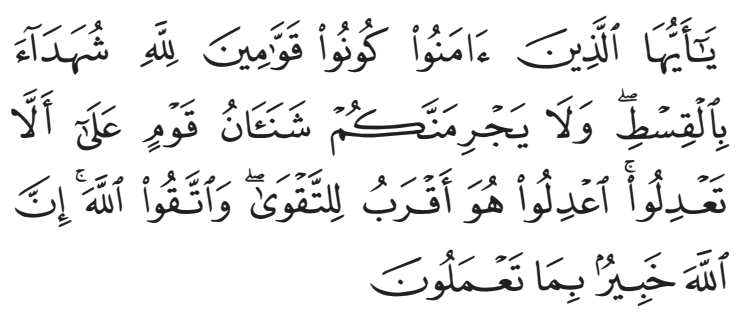

"Wahai orang-orang yang beriman hendaklah kamu sekalian menjadi orang-orang yang tegak membela (kebenaran) karena Allah menjadi saksi (pengukur kebenaran) yang adil. Dan janganlah kebencian kamu pada suatu kaum menjadikan kamu berlaku tidak adil. Berbuat adillah karena keadilan itu lebih mendekatkan pada taqwa. Dan bertaqwalah kepada Allah, karena sesungguhnya Allah Maha Melihat apa yang kamu kerjakan. (QS. al-Maidah: 8) ${ }^{22}$

Ayat ini menegaskan bahwa keadilan bisa terwujud jika unsur-unsur kebencian terhadap seseorang atau golongan tertentu

\footnotetext{
${ }^{21}$ Ibid., h. 131

${ }^{22}$ Ibid., h. 108
} 
dihilangkan. Jika unsur kebencian ini tidak dihilangkan maka hanya akan melahirkan ketidakadilan di tengah-tengah masyarakat.

\section{d. Tasamuh}

Yang dimaksud dengan sikap tasamuh atau toleransi di sini yakni sikap menghargai perbedaan serta menghormati orang yang memiliki prinsip hidup yang tidak sama. Namun bukan berarti mengakui atau membenarkan keyakinan yang berbeda tersebut dalam meneguhkan apa yang diyakini. Firman Allah Swt:

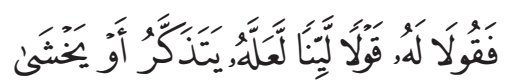

"Maka berbicaralah kamu berdua (Nabi Musa AS dan Nabi Harun AS) kepadanya (Fir'aun) dengan kata-kata yang lemah lembut dan mudah-mudahan ia ingat dan takut. (QS. Thaha: 44$)^{23}$

Walaupun Fir'aun mimiliki keyakinan yang berbeda dengan nabi musa, beliau tetap disuruh berkata lembut dengan fir'an. kelembutan disini merupakan manifestasi dari sikap toleransi namun bukan bermakna membenarkan keyakinannya Fir'aun.

\section{Analisis dan Pembahasan Data Penelitian}

Berikut ini beberapa persepsi masyarakat kota Bengkulu terhadap paham Islam Moderat, antara lain:

a) Paham Islam Moderat adalah ajaran Islam yang bersifat tasamuh (toleran), tawazun (berimbang), i'tidal (lurus) dan tawasuth (sedang-sedang)

Sebagian masyarakat kota Bengkulu memiliki persepsi tentang paham Islam Moderat sebagai Islam yang toleran terhadap perbedaan perbedaan yang ada di tengah-tengah Masyarakat. Hal ini seperti data yang telah peneliti dapatkan, antara lain: "Islam Moderat adalah Islam yang lebih menekankan sisi humanis dan sisi toleran

${ }^{23}$ Ibid., h.314 terhadap sesama muslim dan non muslim. Selain itu, Islam Moderat adalah islam yang lebih menerima perbedaan yang ada tengahtengah masyarakat. Islam itu agama yang mudah bukan agama yang sulit bukan pula agama yang keras." ${ }^{4}$

Data selanjutnya, "Sepengetahuan saya Islam Moderat bukan Islam yang membawa ajaran baru. Sisi moderat memang sudah melekat pada agama Islam. Memunculkan istilah Islam Moderat untuk mensyiarkan sisi toleransi dan keramahan agama Islam bukan berarti membuat agama baru atau sekte baru dalam agama Islam." 25

Data selanjutnya, "Islam Moderat itu bukan Islam yang memihak aliran tertentu yang ada dalam Islam. Semua aliran dalam Islam diterima karena aliran ini lebih menekankan nilai-nilai kebersamaan dan toleransi. Jika ada aliran yang berbeda paham ya disilahkan asal tidak mengganggu serta menyalahkan aliran lain" 26

Data selanjutnya, "Paham Islam Moderat adalah ajaran yang mengembangkan nilai-nilai tasamuh, nilai i'tidal, nilai tawazun dan nilai tawasuth. Nilai-nilai ini sudah sejak jaman dahulu dan terus dipelihara hinga saat ini. Kalau sekarang mau dipopulerkan lagi malah bagus." ${ }^{27}$

Data selanjutnya, "Islam Moderat adalah Islam yang tengah-tengah. Memahami ajaran islam selain mengunakan dilil naqli juga menggunakan dalil Aqli. aliran yang dalam bermasyarakat memadukan dua dalil ini menurut saya adalah aliran yang moderat." 28

Dari data-data di atas, dapat ditarik kesimpulan wahwa persepsi masyarakat Kota Bengkulu tentang Islam Moderat adalah islam yang toleran. Mereka melihat sisi toleransi ini muncul ketika ada perbedaan-perbedaan yang terjadi di tengah-tengah masyarakat.

Namun, yang dimaksud dengan sikap tasamuh atau toleransi disini yakni sikap menghargai

\footnotetext{
${ }^{24}$ Ustad Busthomi, wawancara pada tanggal 5 Juni 2017

${ }^{25}$ Ahmad Zaid, wawancara pada tanggal 7 Juni 2017

${ }^{26}$ Boby, wawancara pada tanggal 7 Juni 2017

${ }^{27}$ Ustad Ahmad Sahel, wawancara pada tanggal 5 Juni 2017

${ }^{28}$ Asmuki, wawancara pada tanggal 14 Juni 2017
} 
perbedaan serta menghormati orang yang memiliki prinsip hidup yang tidak sama, bukan berarti mengakui atau membenarkan keyakinan yang berbeda.

Persepsi masyarakat ini sesuai dengan firman Allah Swt:

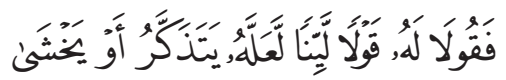
"Maka berbicaralah kamu berdua (Nabi Musa AS dan Nabi Harun AS) kepadanya (Fir'aun) dengan kata-kata yang lemah lembut dan mudahmudahan ia ingat dan takut". (QS. Thaha: 44) ${ }^{29}$

Walaupun Fir'aun mimiliki keyakinan yang berbeda dengan nabi Musa, beliau tetap disuruh berkata lembut dengan Fir'an. Kelembutan di sini merupakan manifestasi dari sikap toleransi namun bukan bermakna membenarkan keyakinannya Fir'aun.

Data di atas juga menunjukan bahwa persepsi masyarak tentang Islam Moderat adalah Islam yang tawazun (berimbang), berimbang disini berarti dalam memahami Islam dilakukan secara proporsional dengan memadukan antara dalildalil yang bersifat naqli dengan dalil-dalil yang bersifat aqli. Pemahaman seperti ini diilhami dari firman Allah Swt surat al-Hadid ayat 25 yang berbunyi:

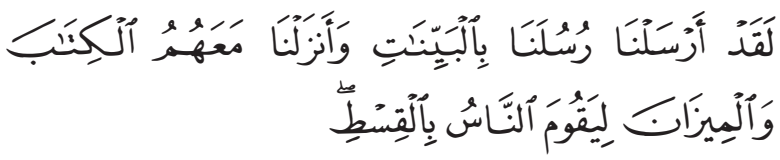

"Sungguh kami telah mengutus rasul-rasul kami dengan membawa bukti kebenaran yang nyata dan telah kami turunkan bersama mereka alkitab dan neraca (penimbang keadilan) supaya manusia dapat melaksanakan keadilan..."(QS. al-Hadid: 25)

Ayat di atas menjelaskan kepada kita bahwa selain al-kitab ada lagi al-mizan yang dijadikan pijakan dalam menjalankan keadilan di dunia ini. Para ulama kemudian menafsiri al-Mizan dengan akal pikiran yang sehat. Namun sesuai dengan ayat di atas yang menjadi barometer awal adalah al-kitab baru kemudian al-mizan

${ }^{29}$ Ibid., h.314 bukan dibalik al-mizan dulu baru al-kitab.

Data di atas juga menunjukan bahwa persepsi masyarakat tentang Islam Moderat adalah Islam i'tidal (lurus). Islam yang dalam melihat fakta sosial dimasyarakat lebih realistis tidak didasarkan atas unsur like atau dislike. Segala sesuatu apabila dilihat dari sisi dislikenya saja, maka seberapa pun bagusnya akan tetap terlihat jelak demikan juga sebaliknya segala sesuatu jika dilihat dari sisi like-nya maka seberapapun jeleknya akan terlihat bagus. Hal ini tentu tidak baik dalam menjaga tatanan bermasyarakat sehinga perlu keberanian untuk berlaku i'tidal dalam bersikap. Pemahaman ini sebenarnya dipahami dari firman Allah:

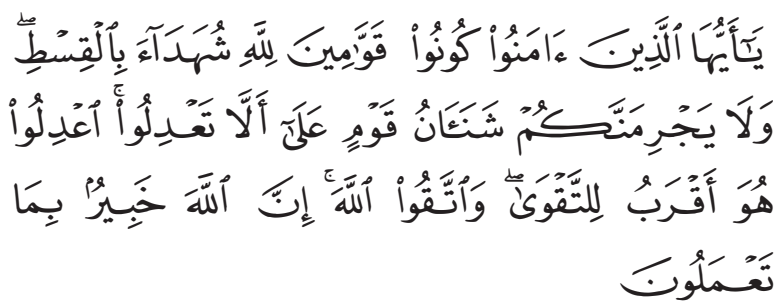

"Wahai orang-orang yang beriman, hendaklah kamu sekalian menjadi orang-orang yang tegak membela (kebenaran) karena Allah, menjadi saksi (pengukur kebenaran) yang adil. Dan janganlah kebencian kamu pada suatu kaum menjadikan kamu berlaku tidak adil. Berbuat adillah, karena keadilan itu lebih mendekatkan pada takwa. Dan bertakwalah kepada Allah, karena sesungguhnya Allah Maha Melihat apa yang kamu kerjakan". (QS al-Maidah [3]: 8)

Ayat ini menegaskan bahwa keadilan bisa terwujud jika unsur-unsur kebencian terhadap seseorang atau golongan tertentu dihilangkan. Jika unsur kebencian ini tidak dihilangkan, maka hanya akan melahirkan ketidakadilan di tengah-tengah masyarakat.

Data di atas juga menunjukan bahwa persepsi masyarakat tentang Islam Moderat adalah Islam tawasuth (sedang-sedang), tidak terlalu condong ekstrim maupun tidak liberal. Memahami islam yang terlalu ekstrim akan melahirkan tindakan anarkis yang membabi buta sedangkan memahami islam secara liberal akan melahirkan sikap mengampangan syari'at. Kedua sikap ini 
baik yang bersifat ekstrimis maupun yang liberal sama-sama hanya akan merusak islam dari dalam. Memahami islam harus dari sisi wastiyah terkadang islam mempunyai sisi keras tapi terkadang juga punya sisi lembut. Islam tidak dipahami selalu keras terus atau selalu lembut terus akan tetapi harus dipahami sesuai dengan porsinya masing-masing.

\section{b) Paham Islam Moderat adalah ajaran Islam yang bersifat Rahmatan Lil Alamin}

Sebagian Masyarakat Kota Bengkulu memiliki persepsi tentang paham Islam Moderat sebagai islam yang Rahmatan Lil Alamin. Islam yang bisa menjadi rahmat bukan untuk kaum muslim saja melainkan untuk seluruh makhluk hidup yang ada di dunia ini. hal ini seperti data yang telah peneliti dapatkan, antara lain: "Islam Moderat adalah Islam yang bisa mengimplementasikan spirit rahmatan lil alamin, apa pun nama aliranya kalau ruh-nya adalah rahmat (kasih saying) itu bagus. ketika kita melihat pelaku kemaksiatan kita harus menegurnya atas dasar kasih sayang bukan atas dasar hinaan. sehinga bisa menjamin keiklasan kita dalam berdakwah"30

Data selanjutnya, "Islam Moderat adalam paham yang yang lahir dari semangat hadis nabi ikhtilafi fi ummati rohmatun (perbedaan yang ada pada umatku adalah rahmat). sehinga mereka mengangap hal wajar kalau dalam islam terdapat banyak perbedaan dalam memahami ajaran Islam." ${ }^{31}$

Dari data di atas bisa diketahui bahwa yang dimaksud dengan Islam Moderat adalah Islam yang rahmatan lil alamin (islam yang menjadi rahmat bagi seluruh alam). Islam yang menjadikan kasih sayang sebagai landasan dalam perjuangan dakwahnya. Jika melihat terdapat dalam suatu daerah ada kemaksiatan yang sedang terjadi maka proses penghentian maksiat tersebut tidak dilakukan dengan cara-cara yang kasar melainkan dilakukan dengan proses yang 2017

${ }^{30}$ Ustad Ahmad Arifin, wawancara pada tanggal 19 Juni

${ }^{31}$ Niamulloh, wawancara pada tanggal 9 Juni 2017 santun. Dasar pelarangan terjadinya maksiat adalah kasih sayang bukan karena menghina, mencela atau mengolok-olok pelaku maksiat.

Demikian juga bila terjadi perbedaan pendapat dalam memahami sesuatu yang terjadi di masyarakat maka tidak serta merta langsung mengklaim pendapatnya sendiri yang paling benar dan menyalahkan pendapat orang lain, melainkan mengangap perbedaan adalah suatu yang wajar bahkan dari perbedaan ini bila bisa dimenej dengan baik maka akan menjadi rahmat bersama. Bukan perbedaan sebenarnya yang menjadi masalah tapi ketidak mampuan mengelola perbedaan ini lah yang bisa jadi masalah. Perbedaan merupakan suatu keniscayaan yang pasti ada di masyarakat sehinga tidak mungkin di hilangkan. Oleh sebab itu, yang terpenting adalah cara memenejnya hinga menjadi suatu rahmat bagi masyarakat.

c) Paham Islam Moderat adalah ajaran Islam yang bersifat humanis, lembut, santun, tidak anarkis dan cinta damai

Sebagian Masyarakat Kota Bengkulu memiliki persepsi tentang paham Islam Moderat sebagai Islam yang humanis, lembut, santun, tidak anarkis dan cinta damai. hal ini seperti data yang telah peneliti dapatkan, antara lain: "Islam Moderat adalah islam yang lebih menekankan sisi humanis dan sisi toleran terhadap sesama muslim dan non muslim. Selain itu Islam Moderat adalah Islam yang lebih menerima perbedaan yang ada di tengah-tengah masyarakat. Islam itu agama yang mudah bukan agama yang sulit bukan pula agama yang keras." 32

Data selanjutnya, "Islam Moderat adalah islam yang tidak anarkis, cinta damai dan toleran. jika Negara damai ekonomi juga bisa berkembang dengan baik. paham moderat harus diajarkan keanak-anak kita sehinga kedepan paham anarkis bisa hilang. hidup tidak nyaman kalau kita dihantui dengan kondisi yang tidak stabil." 33

\footnotetext{
${ }^{32}$ Ustad Busthomi, wawancara pada tanggal 5 Juni 2017

${ }^{33}$ Dani, wawancara pada tanggal 22 Juni 2017
} 
Data selanjutnya, "Islam Moderat adalah Islam yang tidak memaksakan ajarannya kepada orang lain. bila konteksnya bernegara maka yang digunakan ya aturan bernegara. misalkan muncul masalah atau kejahatan dimasyarakat kan tinggal lapor saja kepihak berwajib, nanti akan diselesaikan oleh mereka. Tidak perlu lah kita anarkis atau berbuat radikal dengan maen hakim sendiri." 34

Data selanjutnya, "kalau tidak salah Islam Moderat itu Islam yang mudah diajak diskusi, mudah di ajak berdilog dan mudah menerima kebenaran. Bila anda teriak sampai tenggorokan kering "saya Islam Moderat saya Islam Moderat" tapi diri anda susah kalau diajak berdialog, maka sebenrnya anda adalah penganut Islam ekstrimis" 35

Data selanjutnya, "Islam Moderat mungkin islam yang tidak suka berperang dan membunuh manusia yang tidak sepaham dengan alirannya. lawan dari Islam Moderat adalah islam radikal yang menyukai kekerasan dan tidak segansegan untuk berperang. paham radikal sangat berbahaya bila dibiarkan tumbuh dinegara kita. Tentu kita tidak ingin Negara yang kita cintai ini seperti Negara di timur tengah yang hancur akibat perang saudara. Negara kita Negara yang damai oleh karena itu harus kita jaga secara bersama-sama kedamainya. kalau ada paham radikal yang mencoba menyusup harus kita lawan secara bersama-sama." 36

Data selanjutnya, "Islam Moderat adalah Islam yang cinta damai dan tidak suka berperang. berbeda dengan islam radikal yang sukanya mengobarkan perang dimana-mana seperti ISIS." ${ }^{37}$

Data selanjutnya, "Menurut saya Islam Moderat itu bukan Islam ekstimis. artinya apapun organisasinya kalau mengusung nilainilai yang santun, toleran, cinta damai dan menerima perbedaan pendapat dengan lapang

\footnotetext{
${ }^{34}$ Anto, wawancara pada tanggal 22 Juni 2017

${ }^{35}$ Sairi, wawancara pada tanggal 16 Juni 2017

${ }^{36}$ Nasrun, wawancara pada tanggal 22 Juni 2017

${ }^{37}$ Agnes Cristina, wawancara pada tanggal 23 Juni 2017
}

dada adalah Islam Moderat. jadi Islam Moderat bisa menjelma menjadi banyak organisasi tidak tertentu pada ormas tertentu saja." 38

Data selanjutnya, "Islam Moderat adalah Islam yang anti kekerasan dan anti terorisme. paham ini sangat mengecam para pelaku bom bunuh diri. yang betul kalau mau jihad ya kepalestina saja karena memeang di Indonesia tidak perlu perang untuk bisa beribadah." ${ }^{39}$

Dari data-data di atas, dapat diketahui bahwa persepsi masyarakat kota Bengkulu mengenai Islam Moderat adalah Islam yang humanis, lembut, santun dan cinta damai. Islam humanis di sini maksudnya Islam yang memanusiakan manusia. Manusia adalah makhluk yang memiliki adab dan etika dalam bermasyarakat, sehingga dalam segala aspek kehidupannya apabila ada masalah harus diselesaikan dengan cara yang beradab dan beretika juga, jangan sampai diselesaikan dengan cara-cara yang hewani yakni dengan cara bertarung dan lain sebagainya. Tindakan anarkis serta main hakim sendiri merupakan manifestasi dari cara-cara hewani ketika menyelesaikan masalah.

Islam adalah agama yang cintai damai dan tidak menyukai terjadinya peperangan. Tindakan teror dan anarkis sangat dilarang dalam Islam bahkan tindakan seperti inilah yang merusak citra Islam. Sering sekali peperangan yang terjadi di Negara-negara timur tengah mengatasnamakan perjuangan agama islam padahal sebenarnya mereka hanya merebutkan kekuasan dan jabatan semata. Islam tidak pernah menganjurkan perang kecuali dalam kondisi terdesak dimana sudah tidak ditemukan solusi jalan keluar lagi. Perang ini pun harus dilakukan dengan penuh adab dan etika dimana wanita dan anak-anak tidak boleh dibunuh. Hal ini berbeda dengan fakta peperangan yang mengatasnamakan agama Islam saat ini dimana banyak mengorbankan anak anak dan para wanita.

\footnotetext{
${ }^{38}$ Sakirman, wawancara pada tanggal 9 Juni 2017

${ }^{39}$ Ustad Zamroni, wawancara pada tanggal 12 Juni 2017
} 
d) Paham Islam Moderat adalah ajaran Islam yang membuka diri dengan kemajuan dan selaras dengan konsep kenegaraan Indonesia

Sebagian Masyarakat Kota Bengkulu memiliki persepsi tentang paham Islam Moderat sebagai islam yang membuka diri dengan kemajuan dan selaras dengan konsep kenegaraan Indonesia. hal ini seperti data yang telah peneliti dapatkan, antara lain: "Islam Moderat itu islam kekinian bila diibaratkan sebuah tren. islam yang tidak kolot dan Islam yang bisa membuka diri dengan kemajuan dan kemajemukan masyarakat moderen" 40

Data selanjutnya, "Islam Moderat kalau menurut saya Islam yang bisa memadukan konsep keagamaan dengan konsep kenegaraan secara proposional. bila bisa memadukan dengan baik konflik horizontal misi diminimalisir. Negara kita adalah Negara hukum jadi biar hukum yang memutuskan benar atau salahnya perbuatan jangan maen hakim sendiri apalagi sampai melakukan perbuatan anarkis." ${ }^{41}$

Data selanjutnya, "Islam Moderat harus memiliki jiwa besar, bila ada orang lain sedang berdakwah yang berbeda aliran jangan maen bubur-bubarin sembarangan tapi lakukanlah sesuai dengan prosedural, Islam Moderat adalah Islam yang menghargai perbedaan. " 42

Data selanjutnya, "Islam Moderat itu Islam yang tidak fanatik buta. Orang kalau sudah fanatik buta susah menerima kebenaran. Mereka beranggapan hanya merekalah yang benar, sedangkan yang lain salah semua. Dengan adanya sosialisai yang baik kepada masyarakat terkait paham Islam Moderat ini, saya berharap fanatisme yang ada di tengah-tengah masyarakat bisa berkurang " 43

Dari data-data di atas, dapat diketahui bahwa persepsi sebagian masyarakat kota Bengkulu tentang Islam Moderat adalah Islam yang yang membuka diri dengan kemajuan dan selaras

\footnotetext{
${ }^{40}$ Farhan, wawancara pada tanggal 20 Juni 2017

${ }^{41}$ Andika, wawancara pada tanggal 20 Juni 2017

${ }^{42}$ Ustad Efendi, wawancara pada tanggal 16 Juni 2017

${ }^{43}$ Ustat Arif Rahman, wawancara pada tanggal 16 Juni 2017
}

dengan konsep kenegaraan Indonesia. Islam Moderat adalah islam yang menyerab hal-hal baru yang bersifat positif sekaligus bisa melakukan filterisasi terhadap hal-hal yang bersifat negatif. Tidak semua hal yang baru itu harus ditolak namun cukup dilakukan filterisasi terhadap hal-hal yang bersifat negatif. Demikan juga dalam konteks kenegaraan, kehadiran agama islam harus bisa memberikan warna yang sangat signifikan dalam kehidupan bernegara. Undang-undang serta peraturan-peraturan yang dibuat oleh Negara harus selaras dengan agama Islam.

e) Paham Islam Moderat adalah ajaran Islam yang mengedepankan nilai nilai persatuan dan keutuhan berbangsa dan bernegara

Sebagian masyarakat kota Bengkulu memiliki persepsi tentang paham Islam Moderat sebagai Islam yang mengedepankan nilai nilai persatuan dan keutuhan berbangsa dan bernegara. Hal ini seperti data yang telah peneliti dapatkan, antara lain: "Menurut saya, Islam Moderat adalah Islam yang mengedepankan nilai nilai persatuan dan keutuhan berbangsa dan bernegara. Indonesia itu terdiri dari beraneka ragam ras, suku dan agama. Jika antar warganya tidak memiliki sikap moderat mau jadi apa bangsa kita. Saya sangat mendukung paham Islam Moderat, sekalipun saya tidak beragama Islam demi menjaga keutuhan dan persatuan bangsa Indonesia." ${ }^{44}$

Data selanjutnya, "Islam Moderat sangat mendukung NKRI. Islam di Indonesia yang tidak mendukung NKRI pasti berhaluan radikal” 45

Data selanjutnya, "Islam Moderat adalah Islam yang mendukung NKRI dengan mempererat rasa persatuan dan kesatuan bangsa" 46

Dari data di atas, dapat diketahui bahwa persepsi masyarakat kota Bengkulu terhadap Islam Moderat adalah Islam yang mengedepankan nilai-nilai persatuan dan keutuhan berbangsa dan bernegara. Konsep ini selaras dengan spirit

\footnotetext{
${ }^{44}$ Nasution, wawancara pada tanggal 24 Juni 2017

${ }^{45}$ Ardian, wawancara pada tanggal 25 Juni 2017

${ }^{46}$ Sherly Kurniawan, wawancara pada tanggal 21 Juni 2017
} 
hadis hubb al-wathan min al-iman (cinta tanah air adalah sebagian dari iman). Aliran atau ajaran suatu ormas tertentu yang memiliki keinginan untuk merusak persatuan dan kesatuan bangsa Indonesia adalah aliran yang tidak sejalan dengan nilai-nilai keislaman karena justru hubb al-wathan atau cinta tanah air itu diajarkan dalam Islam.

f) Paham Islam Moderat adalah ajaran Islam yang lebih menekankan sisi amar ma'rufnya dari pada sisi nahi mungkarnya

Sebagian masyarakat kota Bengkulu memiliki persepsi tentang paham Islam Moderat sebagai Islam yang lebih menekankan sisi amar ma’rufnya dari pada sisi nahi mungkarnya. Hal ini seperti data yang telah peneliti dapatkan, antara lain: "Islam Moderat adalah Islam yang lebih menonjolkan sisi amar ma'rufnya dan apabila ada kemaksiatan lebih mengedepankan sisi persuasif. Konsep ini bagus dikembangkan pada masyarakat yang plural seperti Indonesia. Paham ini penting untuk terus disebarluaskan demi menjaga keharmonisan bermasyarakat." ${ }^{47}$

Dari data di atas, dapat disimpulkan bahwa persepsi sebagian masyarakat kota Bengkulu tetang Islam Moderat adalah Islam yang lebih menekankan sisi amar márufnya dari pada sisi nahi mungkarnya. Biasanya dalam berdawah materinya berisi tentang Fadha'ilul A'mal (keutamaan-keutamaan amal). Dakwah mereka bisanya lebih cepat diterima oleh masyarakat karena sifatnya memberi motivasi bukan menyalahkan atau memvonis haram.

\section{g) Paham Islam Moderat adalah ajaran Islam yang bersifat tegas untuk urusan akhirat dan lentur untuk urusan dunia}

Sebagian masyarakat kota Bengkulu memiliki persepsi tentang paham Islam Moderat sebagai Islam yang bersifat tegas untuk urusan akhirat dan lentur untuk urusan dunia. Hal ini seperti data yang telah peneliti dapatkan, antara lain: "Islam Moderat itu Islam yang kalau untuk

\footnotetext{
${ }^{47}$ Maryam, wawancara pada tanggal 19 Juni 2017
}

urusan dunia tidak terlalu mengejar dan lebih toleran, sedangkan kalau untuk urusan akhirat maka tidak bisa ditawar-tawar lagi. Contoh kecil, bila adzan di masjid sudah berkumandang, maka harus segera ke masjid untuk salat dan tidak menunda-nunda dengan alasan masih sibuk" $^{48}$

Data selanjutnya, "Islam Moderat adalah Islam yang toleransi dalam konteks bermuamalah. Moderat harus ditempatkan pada porsi yang sebenarnya jangan ditempatkan pada hal-hal yang melampaui batas itu namanya kebablasan atau liberal. Namanya nanti tidak moderat lagi, misalnya pada hal-hal prinsip yang bersifat tauhid. Ajaran-ajaran prinsip dalam agama Islam tidak boleh ditawar-tawar lagi. seperti masalah kepemimpinan dalam Islam" 49

Dari data di atas, bisa diketahui bahwa sebagian masyarakat kota Bengkulu memiliki persepsi tentang paham Islam Moderat adalah sebagai Islam yang bersifat tegas untuk urusan akhirat dan lentur untuk urusan dunia. Akhirat di sini bermakna hal-hal yang bersifat ketauhidan seperti sifat-sifat tuhan, Tuhan itu esa dan lain sebagainya. Dalam bahasa yang sederhana lagi, persoalan akhirat di sini bisa juga dimaknai dengan rukun iman dan rukun Islam. Sedangkan urusan dunia adalah urusan kemasyarakatan, seperti urusan jual beli, ketatanegaraan dan lain sebagainya.

\section{h) Paham Islam Moderat adalah ajaran Islam yang bersifat liberal dan sesat}

Sebagian masyarakat kota Bengkulu memiliki persepsi tentang paham Islam Moderat sebagai Islam yang bersifat liberal dan sesat. Hal ini seperti data yang telah peneliti dapatkan, antara lain: "Islam Moderat saat ini banyak ditunggangi oleh aliran liberal dalam Islam. kalau menurut saya Islam Moderat itu nama lain dari Islam liberal karena memang sangat mirip pola pikir para penganutnya." 50

\footnotetext{
${ }^{48}$ Kiki, wawancara pada tanggal 16 Juni 2017

${ }^{49}$ Ustad Wahyudi, wawancara pada tanggal 12 Juni 2017

${ }^{50}$ Ustad Usman, wawancara pada tanggal 9 Juni 2017
} 
Data selanjutnya, "Islam Moderat itu sesat, aliran yang mengunakan akal sebagai pedoman adalah aliran sesat dan menyimpang dari yang diajarkan oleh Rosullulah saw, Islam yang betul adalah LDII dimana Alquran dan hadis dijadikan dasar utam dalam berpijak bukan akal. Kalau akal yang dijadikan dasar, maka yang muncul adalah akal-akalan"51

Data selanjutnya, "Yang saya pahami Islam Moderat itu Islam yang ngawur, meraka asalasalan dalam beribadah dan semaunya sendiri dalam membuat hukum. aliran ini sengaja dilahirkan oleh orang-orang liberal yang mendewa-dewakan kebebasan tak terbatas" 52

Dari data-data di atas, dapat diketahui bahwa sebagian masyarakat kota Bengkulu memiliki persepsi tentang paham Islam Moderat adalah sebagai Islam yang bersifat liberal dan sesat. Liberal pada Islam Moderat terjadi karena tidak ada lagi batasan batasan kebebasan yang digaung-gaungkan oleh kelompok mereka. Hal ini terjadi karena mereka menjadikan akal sebagai barometer utama dalam berdalil, yang akan melahirkan akal-akalan dalam berdalil. Kesesatan yang ada pada Islam Moderat juga karena mereka asal-asalan dalam beribadah. Ibadah tidak dilakukan dengan sunguh-sunguh cukup dilakukan dengan sedang sedang saja. Padahal yang bersunguh-sunguh dalam beribadah saja belum tentu diterima ibadahnya apalagi yang sedang-sedang saja kesunguhan dalam beribadahnya.

\section{i) Paham Islam Moderat adalah ajaran Islam yang bersifat bid'ah dan melemahkan umat Islam.}

Sebagian masyarakat kota Bengkulu memiliki persepsi tentang paham Islam Moderat sebagai islam yang bersifat bid'ah dan memecah belah umat. hal ini seperti data yang telah peneliti dapatkan, antara lain: "Islam Moderat itu istilah yang tidak ada dalam ajaran islam. ini istilah

\footnotetext{
${ }^{51}$ Ustad Imam Purwoko, wawancara pada tanggal 15 Juni 2017

52 Ustad Salim, wawancara pada tanggal 15 Juni 2017
}

baru dan bid'ah yang dimunculkan untuk memperlemah agama islam. saya tidak suka kalau islam itu dipecah belah seolah islam satu dengan yang lainya berbeda. Ada islam nusantara ada Islam Moderat ada islam ekstrimis ada islam konvensional dan lain sebagainya. islam itu satu sehinga kalau ingin mengetahui islam yang sejati ya dilihat dari seluruh ajaranya jangan hanya dilihat satu sisi saja." 53

Data selanjutnya, "Islam Moderat merupakan bentuk pelemahan terhadap ajaran Islam. Umat Islam digiring supaya meningalkan ajarannya secara perlahan-lahan dengan doktrin mengamalkan ajaran Islam cukup sedang sedang saja. Umat muslim seharusnya berpegang teguh kepada ajaranya tanpa perlu menawar-nawar lagi. Apa pun yang diperintahkan dalam syariat Islam harus dipraktekkan." 54

Dari data-data di atas, diketahui bahwa sebagian masyarakat kota Bengkulu memiliki persepsi tentang Islam Moderat sebagai Islam yang bersifat bid'ah dan melemahkan umat Islam. Bid'ah merupakan ajaran yang tidak ada tapi sengaja di ada adakan. Melihat Islam tidak bisa hanya dari satu sisi saja. Islam harus dilihat secara komprehensip baik dari sisi lembutnya ataupun dari sisi kerasnya. Upaya melihat Islam hanya dari sebagian sisinya saja merupakan upaya untuk melemahkan umat Islam, karena umat Islam sengaja digiring agar mengamalkan Islam tidak secara komprehensip melainkan cukup mengamalkan sebagian ajarannya saja.

\section{j) Paham Islam Moderat adalah ajaran Islam yang bersifat fatamorgana dan memecah belah umat Islam}

Sebagian masyarakat kota Bengkulu memiliki persepsi tentang paham Islam Moderat sebagai ajaran Islam yang bersifat fatamorgana dan memecah belah umat Islam. Hal ini seperti data yang telah peneliti dapatkan, antara lain: "Paham Islam Moderat sekarang ini masih fatamorgana semata. Saya bingung melihat orang yang selalu

\footnotetext{
${ }^{53}$ Zaini, wawancara pada tanggal 20 Juni 2017

${ }^{54}$ Yusuf Romadhoni, wawancara pada tanggal 15 Juni 2017
} 
mendengung-dengungkna Islam Moderat ternyata tidak moderat juga dalam menerima perbedaan paham yang ada dalam Islam. Mereka toleransi untuk orang-orang yang non muslim tapi tidak toleransi sesama muslim sendiri. Contohnya ketika melihat orang berjenggot, mereka benci, apabila melihat orang isbal, mereka tidak suka. Seharusnya tidak seperti itu, kalau mau moderat ya untuk semua aliran yang ada dalam Islam, bukan hanya moderat untuk non Islam." ${ }^{25}$

Data selanjutnya, "Istilah moderat itu lebel yang sengaja diciptakan oleh pihak asing bagi ormas Islam yang ada di indonesia. Ormas yang kritis dan menentang keras sitem ekonomi kapitalis yang mengancam hegemoni investasi mereka di Indonesia, mereka beri lebel dengan radikal sedangkan ormas yang masih bisa diajak kerja sama dan lebih soft terhadap mereka dilabeli dengan Islam Moderat, Islam yang toleran. ${ }^{56}$

Dari data-data di atas, diketahui bahwa sebagian masyarakat kota Bengkulu memiliki persepsi tentang Islam Moderat sebagai ajaran Islam yang bersifat fatamorgana dan memecah belah umat Islam. Fatamorgana di sini muncul karena selama ini mereka memberikan lebel toleran untuk ajaran Islam Moderat mereka sendiri, tapi di satu sisi mereka ingin menghancurkan paham dan ajaran yang tidak sejalan dengan mereka. Hal ini seperti pedang yang tajam keluar tapi tumpul kedalam. Ajaran lain harus toleran terhadap Islam Moderat tapi Islam Moderat tidak mau toleran dengan ajaran lain yang tidak sejalan. Pemberian lebel moderat dan tidak moderat juga ternyata didasarkan pada apakah aliran mereka mengancam hegomoni investasi asing di Indonesia. Ormas yang kritis dan menentang keras sitem ekonomi kapitalis yang mengancam hegemoni investasi mereka di Indonesia, mereka beri lebel dengan radikal, sedangkan ormas yang masih bisa diajak kerjasama dan lebih soft terhadap mereka, dilabeli dengan Islam Moderat, Islam yang

\footnotetext{
${ }^{55}$ Ahmad Wahid, wawancara pada tanggal 12 Juni 2017

${ }^{56}$ Ustad Zakaria, wawancara pada tanggal 14 Juni 2017
}

toleran. Tujuan akhir dari pelebelan ini adalah untuk memecah belah umat Islam sehinga tidak memiliki kekuatan untuk menghancurkan hegomoni investasi asing di Negara Indonesia.

Secara garis besar, persepsi masyarakat kota Bengkulu terhadap Islam Moderat terbagi menjadi dua kategori, yakni persepsi yang baik dan persepsi yang tidak baik. Untuk lebih jelasnya, bisa dilihat pada tabel di bawah ini:

\begin{tabular}{cll}
\hline \multirow{2}{*}{ No } & \multicolumn{1}{c}{$\begin{array}{l}\text { Persepsi Masyarakat Kota Bengkulu Terhadap Islam } \\
\text { Moderat }\end{array}$} \\
\cline { 2 - 3 } & \multicolumn{1}{c}{ Persepsi Baik } & \multicolumn{1}{c}{ Persepsi Tidak Baik } \\
\hline 1 & $\begin{array}{l}\text { Paham Islam Moderat } \\
\text { adalah ajaran Islam } \\
\text { yang bersifat tasamuh } \\
\text { (toleran), tawazun } \\
\text { (berimbang), i'tidal } \\
\text { (lurus) dan tawasuth } \\
\text { (sedang-sedang) }\end{array}$ & $\begin{array}{l}\text { Paham Islam Moderat } \\
\text { adalah ajaran Islam yang } \\
\text { bersifat liberal dan sesat }\end{array}$ \\
\hline 2 & $\begin{array}{l}\text { Paham Islam Moderat } \\
\text { adalah ajaran Islam yang } \\
\text { bersifat Rahmatan Lil } \\
\text { Alamin }\end{array}$ & $\begin{array}{l}\text { Paham Islam Moderat } \\
\text { adalah ajaran Islam } \\
\text { yang bersifat bid'ah dan } \\
\text { melemahkan umat Islam }\end{array}$ \\
\hline 3 & $\begin{array}{l}\text { Paham Islam Moderat } \\
\text { adalah ajaran Islam yang } \\
\text { bersifat humanis, lembut, } \\
\text { santun, tidak anarkis dan } \\
\text { cinta damai }\end{array}$ & $\begin{array}{l}\text { Paham Islam Moderat } \\
\text { adalah ajaran Islam yang } \\
\text { bersifat fatamorgana dan } \\
\text { memecah belah umat Islam }\end{array}$ \\
\hline 4 & $\begin{array}{l}\text { Paham Islam Moderat } \\
\text { adalah ajaran Islam yang } \\
\text { bersifat tegas untuk } \\
\text { urusan akhirat dan lentur } \\
\text { untuk urusan dunia } \\
\text { adalah ajaran Islam } \\
\text { yang membuka diri } \\
\text { dengan kemajuan dan } \\
\text { selaras dengan konsep } \\
\text { kenegaraan Indonesia }\end{array}$ & \\
\hline 5 & $\begin{array}{l}\text { Paham Islam Moderat } \\
\text { adalah ajaran Islam } \\
\text { yang mengedepankan } \\
\text { nilai-nilai persatuan dan } \\
\text { keutuhan berbangsa dan } \\
\text { bernegara }\end{array}$ & \\
\hline $\begin{array}{l}\text { Paham Islam Moderat } \\
\text { adalah ajaran Islam yang } \\
\text { lebih menekankan sisi } \\
\text { amar ma'rufnya dari pada } \\
\text { sisi nahi mungkarnya }\end{array}$ & \\
\hline & \\
\hline
\end{tabular}


Dari data di atas, dapat diketahui bahwa sebagian besar masyarakat kota Bengkulu memiliki persepsi yang baik tentang paham Islam Moderat, hal ini dapat dilihat pada tabel di bawah ini:

\begin{tabular}{cccc}
\hline No & $\begin{array}{c}\text { Persepsi Masyarakat Kota } \\
\text { Bengkulu Terhadap Urgensi } \\
\text { Penyebaran Paham Islam Moderat }\end{array}$ & $\begin{array}{c}\text { Persentase } \\
\%\end{array}$ \\
\hline $\mathbf{1}$ & $\begin{array}{c}\text { Persepsi Yang } \\
\text { Baik }\end{array}$ & $\begin{array}{c}\text { Ada 7 persepsi } \\
\text { yang baik }\end{array}$ & $70 \%$ \\
\hline $\mathbf{2}$ & $\begin{array}{c}\text { Persepsi Yang } \\
\text { Tidak Baik }\end{array}$ & $\begin{array}{c}\text { Ada 3 persepsi } \\
\text { yang tidak baik }\end{array}$ & $30 \%$ \\
&
\end{tabular}

\section{Penutup}

Dari pemaparan dan pembahasan data di atas, dapat ditarik kesimpulan bahwa masyarakat kota Bengkulu memiliki beberapa persepsi tentang paham islam moderat, antara lain: pertama, paham Islam Moderat adalah ajaran Islam yang bersifat tasamuh (toleran), tawazun (berimbang), itidal (lurus) dan tawasuth (sedanga-sedang). Kedua, paham Islam Moderat adalah ajaran Islam yang bersifat Rahmatan Lil Alamin. Ketiga, paham Islam Moderat adalah ajaran Islam yang bersifat humanis, lembut, santun, tidak anarkis dan cinta damai. Keempat, paham Islam Moderat adalah ajaran Islam yang membuka diri dengan kemajuan dan selaras dengan konsep kenegaraan Indonesia. Kelima, paham Islam Moderat adalah ajaran Islam yang mengedepankan nilai-nilai persatuan dan keutuhan berbangsa dan bernegara. Keenam, paham Islam Moderat adalah ajaran Islam yang lebih menekankan sisi amar ma’rufnya dari pada sisi nahi mungkarnya. Ketujuh, paham Islam Moderat adalah ajaran Islam yang bersifat tegas untuk urusan akhirat dan lentur untuk urusan dunia. Kedelapan, paham Islam Moderat adalah ajaran Islam yang bersifat liberal dan sesat. Kesembilan, paham Islam Moderat adalah ajaran Islam yang bersifat bid'ah dan melemahkan umat islam. Kesepuluh, paham Islam Moderat adalah ajaran Islam yang bersifat fatamorgana dan memecah belah umat Islam.

\section{Pustaka Acuan}

Abu Syamsi, wawancara pada tanggal 6 Juni 2017

Agnes Cristina, wawancara pada tanggal 23 Juni 2017

Ahmad Dahlan, wawancara pada tanggal 6 Juni 2017

Ahmad Fasikhudin, Islam Moderat, Bandung: Insan Kamil, 2010.

Ahmad Wahid, wawancara pada tanggal 12 Juni 2017

Ahmad Zaid, wawancara pada tanggal 7 Juni 2017

Ahmad, wawancara pada tanggal 29 Maret 2017.

Airen Celinesia, wawancara pada tanggal 21 Juni 2017

Ali Zainal, wawancara pada tanggal 14 Juni 2017

Andi, wawancara pada tanggal 22 Juni 2017

Andika, wawancara pada tanggal 20 Juni 2017

Anita, wawancara pada tanggal 23 Juni 2017

Anto, wawancara pada tanggal 22 Juni 2017

Ardian, wawancara pada tanggal 25 Juni 2017

Asmuki, wawancara pada tanggal 14 Juni 2017

Atkinson dkk, Pengantar Psikologi Jilid II, Batam: Intereksa, 1987.

Bakri, Syamsul, "Islam dan Wacana Radikalisme Kontemporer”. DINIKA. Vol. 3 No. 1, Januari 2004.

Basrowi, Muhammad dan Soeyono, Teori Sosiologi dalam Tiga Paradigma, Surabaya: Yayasan Kampusina, 2004.

Boby, wawancara pada tanggal 7 Juni 2017

BPS Provinsi Bengkulu, Provinsi Bengkulu Dalam Angka 2016, Bengkulu: Perum Percetakan Negara RI Cabang Bengkulu, 2016.

Dani, wawancara pada tanggal 22 Juni 2017

Darto, wawancara pada tangal 24 Maret 2017.

Emanuel, wawancara pada tanggal 23 Juni 2017

Farhan, wawancara pada tanggal 20 Juni 2017 
Gracia Stefani, wawancara pada tanggal 23 Juni 2017

Hasan, Muhammad Tholhah, Ahlussunah Wal Jamaah, Jakarta: Lantabora Press, 2005.

Ibnu Aqil, wawancara pada tanggal 19 Juni 2017

Igusti Ananta, wawancara pada tanggal 26 Juni 2017

Imade Jaya, wawancara pada tanggal 25 Juni 2017

Irsad Hakim, wawancara pada tanggal 13 Juni 2017

Kartono, Kartini, Psikologi Umum, Bandung: Insan Kamil, 1984.

Kiki, wawancara pada tanggal 16 Juni 2017

Kundarto Sahid, wawancara pada tanggal 20 Juni 2016

Linda, Davidoff, Psikologi Suatu Pengantar, Jakarta: Erlanga, 1988.

Mada Kusuma, wawancara pada tanggal 241Juni 2017

Madjid, Nurcholish, Islam Kemoderenan dan Keindonesiaan, Bandung : Mizan, 1998.

Mahmud, Dimyati, Psikologi Suatu Pengantar, Jakarta: BPFE, 1990.

Maichel, wawancara pada tanggal 24 Juni 2017

Manshur, wawancara pada tanggal 19 Juni 2017

Mar'at, Sikap Manusia, Perubahan, dan Pengukurannya, Jakarta: Ghalia Indonesia, 1981.

Maryam, wawancara pada tanggal 19 Juni 2017

Michel, W. dan N.H. Michel, Essentials of Psychology, New York: Rndom House Inc., 1980.

Miftahuddin, Dosen Prodi Ilmu Sejarah, Jurusan Pendidikan Sejarah, FISE UNY, "Islam Moderat Konteks Indonesia Dalam Perspektif Historis".

Moleong, Lexy J., Metodologi Penelitian Kualitatif, Bandung: PT Remaja Rosdakarya, 2012.

Muhammad, Abdul Kadir, Hukum dan Penelitian Hukum, Jakarta: PT. Citra Aditya Bhakti, 2004.
Muzakki, wawancara pada tangal 24 Maret 2017

Nasrun, wawancara pada tanggal 22 Juni 2017

Nasution, wawancara pada tanggal 24 Juni 2017

Newcomb, Theodore M. dkk., Psikologi Sosial, Bandung: Dipenogoro, 1981.

Niamulloh, wawancara pada tanggal 9 Juni 2017

Putu Kusuma, wawancara pada tanggal 26 Juni 2017

Rahman, Fazlur, Islam, (Bandung : Pustaka, 1997)

Rakhmat, Jalaluddin, Psikologi Umum, Bandung: Insan Kamil, 1984.

Rijal, wawancara pada tangal 27 Maret 2017

Rudi, wawancara pada tanggal 20 Juni 2017

Sa'diyah, Sri Utami, Persepsi Siswa Terhadap Guru Pendidikan Agama Islam Yang Ideal, Situbondo: Ibrahimy Press, 2009.

Sairi, wawancara pada tanggal 16 Juni 2017

Sakirman, wawancara pada tanggal 9 Juni 2017

Salman, wawancara pada tanggal 9 Juni 2017

Saputra, Faiz, wawancara pada tanggal 7 Juni 2017

Sarwono, Sarlito Wirawan, Pengantar Psikologi, Jakarta: Bulan Bintang, 1976.

Shaleh, Abdul Rahman, Muhbib Abdul Wahab, Psikologi Suatu Pengantar Dalam Perspektif Islam, Jakarta: Kencana, 2004.

Sherly Kurniawan, wawancara pada tanggal 21 Juni 2017

Sholihan, Modernitas Postmodernitas Agama, Semarang: Walisongo Press, 2008.

Sholikhin, M., Sejarah Peradaban Islam, Semarang: Rasail, 2005.

Su'adah, Fauzik Lendriyono, Pengantar Psikologi, Malang: Bayumedia Publishing, 2003.

Sugiyono, Model Penelitian Kuantitatif Kualitatif, Bandung: Alfabeta, 2010.

Suhidi, wawancara pada tanggal 13 Juni 2017

Sumarna, wawancara pada tanggal 11 Juni 2017

Susanti, wawancara pada tanggal 24 Juni 2017 
Umar, Husein, Metode Penelitian Untuk Skripsi dan Tesis Bisnis, Jakarta: PT Raja Grafindo Persada, 2009.

Usman, Husaini dan Purnomo Setiady Akbar, Metodologi Penelitian Sosial, Jakarta: PT Bumi Aksara, 2003.

Ustad Ahmad Arifin, wawancara pada tanggal 19 Juni 2017

Ustad Ahmad Sahel, wawancara pada tanggal 5 Juni 2017

Ustad Arif Rahman, wawancara pada tanggal 16 Juni 2017

Ustad Badrud, wawancara pada tanggal 5 Juni 2017

Ustad Busthomi, wawancara pada tanggal 5 Juni 2017

Ustad Dadang, wawancara pada tanggal 15 juni 2017

Ustad Efendi, wawancara pada tanggal 16 Juni 2017

Ustad Imam Purwoko, wawancara pada tanggal 15 Juni 2017

Ustad Iskandar, wawancara pada tanggal 5 Juni 2017

Ustad Muttaqin, wawancara pada tanggal 19 Juni 2017

Ustad Pendi, wawancara pada tanggal 17 Juni 2016

Ustad Salim, wawancara pada tanggal 15 Juni 2017

Ustad Suyuti, wawancara pada tanggal 14 Juni 2017
Ustad Usman, wawancara pada tanggal 9 Juni 2017

Ustad Wahyudi, wawancara pada tanggal 12 Juni 2017

Ustad Zaini Makmun, wawancara pada tanggal 6 Juni 2017

Ustad Zakaria, wawancara pada tanggal 14 Juni 2017

Ustad Zamroni, wawancara pada tanggal 12 Juni 2017

Walgito, Bimo, Pengantar Psikologi Umum, Yogyagkarta: Andi Offsed, 1994.

Wawan, wawancara pada tanggal 16 Juni 2017

Wayan Saputra, wawancara pada tanggal 25 Juni 2017

Subyakto, Psikologi Sosial, Jakarta: Haruhita, 1988.

Wulan, wawancara pada tanggal 23 Juni 2017

Yanto, wawancara pada tangal 29 Maret 2017

Yatim, Badri, Sejarah Peradaban Islam, Jakarta: Rajawali Pers, 2010.

Yunus, wawancara pada tanggal 16 Juni 2017

Yusuf Romadhoni, wawancara pada tanggal 15 Juni 2017

Zaini, wawancara pada tanggal 20 Juni 2017

Zainudil Al-Afgani, wawancara pada tanggal 6 Juni 2017

Zakiya Yusuf, wawancara pada tanggal 12 Juni 2017

Zuriah, Nurul, Metodologi Penelitian Sosial dan Pendidikan, Jakarta: PT Bumi Aksara, 2009. 